DEPARTMENT OF THE INTERIOR

U.S. GEOLOGICAL SURVEY
OPEN-FILE REPORT 97-475

Explanatory pamphlet accompanies map

\title{
GEOLOGIC MAP OF THE NABESNA A-6 QUADRANGLE, ALASKA
}

By

Donald H. Richter ${ }^{1}$, Elizabeth Moll-Stalcup ${ }^{2}$, Wendell A. Duffield ${ }^{3}$, and Nora Shew ${ }^{1}$

OPEN-FILE REPORT 97-475

This report is preliminary and has not been reviewed for conformity with U.S. Geological Survey editorial standards (or with the North American Stratigraphic Code).

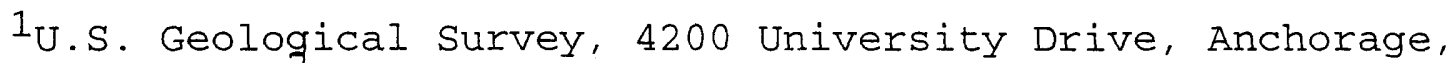
AK 99508; 12022 Lake Newport Rd., Herndon, VA 22070;

${ }^{3}$ U.S. Geological Survey, 2255 North Gemini Drive, Flagstaff, AZ 86001 
DEPARTMENT OF THE INTERIOR

U.S. GEOLOGICAL SURVEY
OPEN-FILE REPORT 97-475

PAMPHLET

\author{
INTRODUCTORY NOTE, DESCRIPTION OF MAP UNITS, CHEMICAI \\ ANALYSES, RADIOMETRIC AGES, AND REFERENCES \\ For the
}

GEOLOGIC MAP OF THE NABESNA A-6 QUADRANGLE, ALASKA

By

Donald H. Richter, Elizabeth Moll-Stalcup, Wendell A. Duffield, and Nora Shew

CONTENTS

Introductory Note

Description of Map Units 2

References 15

TABLES

Table 1. K-Ar ages and analytical data on volcanic rocks from the Nabesna A-6 quadrangle, Alaska.

Table 2. Chemical analyses of volcanic rocks from the Nabesna A-6 quadrangle, Alaska.

FIGURES

Figure 1. Index map showing study area (shaded), surrounding 1:250,000-scale quadrangles, neighboring geologically-mapped 1:63,360-scale quadrangles, and some principal geographic features.

Figure 2. Rare earth element (REE) data, chondritenormalized, for rocks from the Nabesna A-6 quadrangle, Alaska. 


\section{INTRODUCTORY NOTE}

The Nabesna A-6 quadrangle is in the northwest part of the extensive $\left(>10,000 \mathrm{~km}^{2}\left(3,800 \mathrm{mi}^{2}\right)\right)$ Wrangell volcanic field of Miocene to Holocene age in south-central Alaska. It includes Mount Jarvis, a large Pleistocene andesite volcano and at least two smaller andesite eruptive centers that extend north from Mount Jarvis. A dacite-andesite dome-flow complex occurs at the north end of the Mount Jarvis chain of andesite volcanoes. The quadrangle also includes parts of the extreme northeast flank of Mount Wrangell and the east flank of Mount Sanford, both large chiefly andesitic Pleistocene shield volcanoes (see Index Map). Bedrock in much of the southwest part of the quadrangle is covered by the extensive ice field on the higher elevations of Mount Wrangell.

\section{DESCRIPTION OF MAP UNITS}

\section{ALLUVIAL DEPOSITS}

Qal Alluvium along streams (Holocene)--Mainly in active flood plains of major and some minor streams. Locally, includes outwash related to older phases of the Alaska glaciations. Chiefly stratified boulders, cobbles, gravel, and sand; silt locally common.

Qaf Alluvium in fans (Holocene)--Mainly large active fans and cones on steep to gentle slopes adjacent to the broad glaciated valley of the Copper River. Chiefly poorly stratified boulders, cobbles, gravel, and sand.

\section{COLLUVIAL DEPOSITS}

QC Colluvium, undifferentiated (Holocene and Pleistocene)--Chiefly talus but also includes deposits of small landslides, rock glaciers, and other mass-wasting processes; in places includes large proportion of alluvium in small fans and cones and locally includes remnants of morainal deposits. Chiefly unsorted boulders, cobbles, gravel, and sand.

\section{GLACIAL DEPOSITS}

Qrg Rock glacier deposits (Holocene and Pleistocene)-Deposits in both active rock glaciers, which have well-defined lobate forms, and inactive rock glaciers, which have smooth forms. Chiefly angular blocks and diamicton. 
Drift of Alaskan glaciation (Holocene)--End, lateral, and ground moraine of the Alaskan glaciations which were deposited during the recession of existing glaciers. In the extensive areas of glacial drift west of Copper Glacier three stages of Alaskan glaciation are recognized (H. Schmoll, written comm., 1994). The youngest stage includes ground, lateral, and end moraines that have been deposited near the margins of present-day glaciers. The two older stages, related to an older phase of Alaskan glaciation and marked by prominent and well-defined lateral moraines, occur further beyond the present-day glacier margins. Dashed line with hachures indicates extent of youngest stage of Alaskan glaciation and locally includes areas within which glaciers have been advancing and retreating during the late 20 th century. Plain dashed line separates the two older stages of Alaskan glaciation. Drift is locally modified by colluvial processes, especially along steep eastside of the large nunatak west of Copper Glacier. Diamicton and rubble; local gravel and sand.

Qwg Drift of Wisconsin glaciation (Pleistocene)--Chiefly lateral and ground moraine of both younger and older stages of Wisconsin glaciation. Diamicton and rubble; local gravel and sand.

Qog Drift of older glaciations (Pleistocene)--Glacial and fluvioglacial deposits observed only in the north wall of the Jacksina Glacier valley where unit is overlain by an agglutinate flow (unit Qaa) that may be as old as $1.38 \mathrm{Ma}$ (Richter and Smith, 1976). Chiefly diamicton; local sand, gravel and boulders.

\section{VOLCANIC ROCKS}

Wrangell volcano--Mount Wrangell (el. 14,163 ft [4317 m]) is a large shield volcano, whose summit area lies mostly to the southwest in the contiguous Gulkana $A-1$ and Valdez D-1 quadrangles. Only a part of the northeast flank of the shield is exposed in the quadrangle. A porphyritic high-silica andesite lava, similar to that found elsewhere on the Wrangell shield (Richter and others, 1994) is the predominant rock type in the quadrangle.

QwC

East Crater deposits (Holocene and Pleistocene)--

Deposits were not examined during this present study. Samples collected from the summit craters by R.B. Forbes, G.B. Wharton, and C.S. Benson of the University of Alaska, Fairbanks, during 1961- 
1967 are altered flows, breccias, and tuffs. One

of these samples from the East Crater is described by Hurst (1968) as an altered olivine-bearing twopyroxene andesite.

Qwa Two-pyroxene high-silica andesite flows (Pleistocene) Medium- to dark-gray, thin to thick $(5-30 \mathrm{~m})$ lava flows that generally exhibit oxidized and slightly scoriaceous tops and bottoms. Rock is conspicuously porphyritic containing phenocrysts (2-7 mm) of plagioclase (15-20 \%), orthopyroxene (1-10\%), clinopyroxene (trace-5 \%), opaque minerals (trace \%), resorbed olivine (0-trace \%), amphibole (0-trace \%), and locally abundant glomerocrystic clots of plagioclase + orthopyroxene \pm clinopyroxene \pm opaque minerals in a pilotaxitic to intersertal ground mass of plagioclase and pyroxene microlites in a glass or cryptocrystalline matrix. Orthopyroxene is invaribly the dominant pyroxene. Some phenocrysts may be largely the result of the disaggregation of glomerocrystic clots. Plagioclase shows evidence of as many as 3 different populations;

orthopyroxene is locally rimmed by clinopyroxene and olivine by orthopyroxene, all suggestive of a mixed magma origin. Rock contains 61.8-63.4\% $\mathrm{SiO}_{2}$ (samples 91ARh-11, 91AMl-5, Table 2); in the contiguous Gulkana A-1 quadrangle, $\mathrm{SiO}_{2}$ content of correlative lavas ranges from 59-62 (Richter and others, 1994). Nye (1983) reports a whole-rock KAr age of $0.5 \pm 0.4 \mathrm{Ma}$ for a flow in sec. 18, T.4 N., R.9 E.; in the contiguous Gulkana A-1 quadrangle, $\mathrm{K}$-Ar ages for correlative lavas range between 0.5 and $0.6 \mathrm{Ma}$ (Richter and others, 1994).

Qwbf Olivine basalt flow and breccia (Pleistocene)--Darkto medium-gray, slightly porphyritic to microporphyritic basalt containing phenocrysts and microphenocrysts $(<1-2 \mathrm{~mm})$ of plagioclase $(5-40$ $\%)$ olivine (1-10\%), and an occasional glomerocrystic clot of plagioclase in a groundmass of dark glass containing microlites of plagioclase and opaque minerals. Larger plagioclase and olivine phenocrysts are strongly resorbed; microphenocrysts are euhedral and fresh. A pillow fragment in the breccia contains $51.6 \% \mathrm{SiO}_{2}$ (sample 91ADf-8, Table 2). Nye (1983) reports a whole-rock $\mathrm{K}$-Ar age of $0.60 \pm 0.02 \mathrm{Ma}$ for the flow rock. Both flow and breccia exhibit textures indicative of interaction between the lava flow and ice. The flow displays exceptionally well-developed swirly columnar joints and the breccia consists largely of pillows and pillow fragments in a hyaloclastite matrix. 
Source may be the cinder cone (unit Qwbc) a few kilometers to the south.

Qwbc Cinder cone (Pleistocene)--Dissected cinder cone, largely covered by glacial ice, consisting of reddish cinder and bombs interbedded with thin scoriaceous flows and overlain, on the south, by south-dipping palagonitic tephra. All rocks probably of basalt or basaltic andesite composition. Rocks are slightly porphyritic containing phenocrysts of plagioclase and olivine in a glassy or cryptocrystalline groundmass. Nye (1983) reports whole rock $K-A r$ ages of $0.60 \pm 0.02$, $0.75 \pm 0.03$, and $0.75 \pm 0.03 \mathrm{Ma}$ on rocks from the cone.

Mount Sanford volcano--Mount Sanford (el. 16,237 ft [4949 $\mathrm{m}])$ is a large, complex shield volcano, lying to the west in the contiguous Gulkana A-1 (Richter and others, 1994) and B-1 quadrangles (Richter and others, 1989). Only flows on a limited part of the southeast flank of the volcano are exposed in the quadrangle.

Qsi Dikes, undifferentiated (Pleistocene)--None of the dikes shown were sampled or examined on the ground. Similar dikes intruding Sanford lavas in the contiguous Gulkana A-1 quadrangle (Richter and others, 1994) are chiefly of andesitic composition.

Qsd Low-silica dacite flows (Pleistocene)--Medium- to dark-gray, sparsely porphyritic, two-pyroxene dacite flows containing phenocrysts (1-4 mm) of plagioclase (1-5\%), clinopyroxene (trace-3\%), orthopyroxene (trace-2 \%), opaque minerals (trace$1 \%)$, and olivine (0-trace $\%$ ) and glomerocrystic or xenocrystic clots of plagioclase + orthopyroxene + clinopyroxene + opaque minerals in a glass groundmass generally containing a few percent plagioclase microlites. Plagioclase phenocrysts are mostly fresh and oscillatory zoned; larger phenocrysts have resorbed cores. An analyzed rock contains $64.6 \% \mathrm{SiO}_{2}$ (sample 91ARh-1, Table 2). Plagioclase yielded $\mathrm{K}$-Ar age of $1.11 \pm 0.03 \mathrm{Ma}$ (sample 91ASh-3, Table 1). This age appears too old in light of volcanic stratigraphy and may be due to excess argon in some of the plagioclase or possibly some of the plagioclase is xenocrystic and the age is indicating an earlier crystallization event. Flows range in thickness from a few meters to as much as $12 \mathrm{~m}$; aggregate thickness may be as much as $500 \mathrm{~m}$. Source either the south sanford 
eruptive center or rifts on the southeast flank of the volcanic center.

Qsy Young basaltic andesite, andesite, and dacite lavas, undifferentiated (Pleistocene)--Light-gray to grayish-black, aphyric to strongly porphyritic lavas. Chiefly olivine basaltic andesite and andesite but includes hypersthene andesite, olivine-hypersthene andesite, two-pyroxene andesite, and dacite. South of the unnamed long, narrow, debris-covered glacier that trends eastwest in the northwest part of the quadrangle, the predominant rocks are olivine basaltic andesites. They are moderately porphyritic and contain phenocrysts and microphenocrysts $(<1-4 \mathrm{~mm})$ of plagioclase $(3-8 \%)$, fresh olivine (1-4\%), clinopyroxene (trace-1 \%) and opaque minerals (trace) in a cryptocrystalline to pilotaxitic groundmass of plagioclase microlites and glass or cryptocrystalline material. Glomerocrystic clots of plagioclase + olivine are locally common and plagioclase in all lavas appears to be of two populations: clear euhedral crystals and coarser grained crystals exhibiting strongly resorbed cores and clear rims. A sample of the porphyritic variety contains $54.8 \% \mathrm{SiO}_{2}$ (sample 91ARh-10, Table 2) and an aphyric sample $56.5 \%$ $\mathrm{SiO}_{2}$ (sample 91ARh-7, Table 2). Sample 91ARh-8A, an olivine-bearing high silica andesite (62.8\% $\mathrm{SiO}_{2}$, Table 2) may be part of the low silica dacite sequence (Qsd) mapped north of the glacier, but the flows contain up to $3 \%$ olivine and no orthopyroxene. North of the unnamed glacier, the lavas are probably chiefly low-silica dacites, the same as those of unit Qsd that are exposed to the east at lower, more accessible, locations. Source of most of the lavas is probably the south Sanford eruptive center in the contiguous Gulkana A-1 quadrangle.

Qsp Dacite pyroclastic flow (Pleistocene)--Flow consists chiefly of very light gray to olive gray pumice, in moderately welded ash. Pumice is locally banded, and occurs in blocks up to $1 \mathrm{~m}$ in diameter. Light colored pumice is sparsely porphyritic containing phenocrysts (1-2 mm) of clear plagioclase (1-3 \%), orthopyroxene (trace to $1 \%$ ), clinopyroxene (trace), and opaque minerals (trace) in a groundmass of plagioclase microlites and clear glass. Darker pumice is mineralogically similar, but contains a darker glass and finer grained plagioclase laths than in the lighter colored pumice. The light pumice contains $69.6 \%$ $\mathrm{SiO}_{2}$ (sample 91AMI-3a, Table 2). Plagioclase 
yielded a $\mathrm{K}-\mathrm{Ar}$ age of $0.62 \pm 0.03 \mathrm{Ma}$ (sample 91ASh-1).

Qso Older volcanic rocks (Pleistocene)--Chiefly

interlayered thick lava flows, flow breccias, and debris and mudflow deposits that are mostly of andesitic or basaltic andesitic composition.

Rocks are separated from overlying Sanford lava flows (units Qsd, Qsy) by slight angular unconformity and may represent an early shieldbuilding phase of Sanford volcano. A mainly aphanitic flow that consists of traces of clinopyroxene and rounded plagioclase crystals in a glassy groundmass contains $63.0 \% \mathrm{SiO}_{2}$ (sample 91ADf-6, Table 2). A whole rock K-Ar age of $0.96 \pm 0.16 \mathrm{Ma}$ was obtained on a flow at the base of unit near localities 8 and 9 (sample 74ALe-27, Richter and others, 1990).

Ho-Hum Creek dome complex --An andesite-dacite dome-flow center $1.5 \mathrm{mi}(2 \mathrm{~km})$ northeast of the north Jarvis eruptive center. Complex consists chiefly of an older, central dome and flows of hornblende dacite and younger flows of andesite and dacite that exhibit mixed magma characteristics, such as the presence of euhedral olivine and reaction-rimmed quartz in the same flow. An irregular body of dacite that intrudes(?) lavas of the Tumble Creek area is described as part of the Ho-hum Creek complex. Age of the complex may be as young as 0.5 Ma as it overlies olivine basaltic andesite flows (unit obf) that erupted less than $1 \mathrm{Ma}$.

Qha Quartz-bearing high silica andesite flow (Pleistocene)--Medium gray to brownish gray sparsely porphyritic andesite flow containing phenocrysts (1-4 mm) of oscillatory-zoned and inclusion-rich plagioclase (1-8\%), rounded and embayed quartz exhibiting clinopyroxene reaction rims (trace-2 \%), clinopyroxene (0-2 \%), euhedral olivine $(0-3 \%)$, and pyroxene + opaque mineral pseudomorphs after amphibole (trace-1 \%) in a trachytic groundmass of alined plagioclase laths, pyroxene, opaque minerals, and brown glass. Glomerocrystic clots of clinopyroxene + plagioclase + opaque minerals are locally abundant. Analyzed rocks contain 59.6-60.3\% $\mathrm{SiO}_{2}$ (samples 91ADf-9, 91ASh-9, Table 2). A plagioclase $\mathrm{K}$-Ar age of $1.06 \pm 0.12 \mathrm{Ma}$ (sample 91ASh-9, Table 1) may be too old due to excess argon resulting from the presence of inclusionrich and/or xenocrystic plagioclase in the rock. Unit is apparently a single flow as much as $150 \mathrm{~m}$ (500 ft) thick. 
Qhad High silica andesite and dacite flows (Pleistocene)-Undifferentiated porphyritic flows containing phenocrysts $(1 \mathrm{~mm}-1 \mathrm{~cm}$ ) of oscillatory-zoned plagioclase (5-25 \%), orthopyroxene (1-6 \%), hornblende $(0-2 \%)$, and occasional traces of clinopyroxene, opaque minerals, and quartz in a cryptocrystalline to glassy groundmass that may contain sparse microlites of plagioclase and orthopyroxene. Glomerocrystic clots of orthopyroxene + plagioclase + opague minerals are locally abundant. Analyzed rocks contain 62.6$64.7 \% \mathrm{SiO}_{2}$ (samples 91AMl-10C, 91ARh-21, Table 2).

Qhdd Dacite dikes (Pleistocene)--Chiefly northerly trending dikes, as much as $5 \mathrm{~m}$ thick, apparently restricted to central part of dome complex. Dikes are medium gray and porphyritic (1-4 mm) containing oscillatory-zoned plagioclase (3-15\%), fresh hornblende (1-3\%), opaque minerals (1-2 \%), and traces of orthopyroxene, clinopyroxene, biotite, and quartz in a trachytic groundmass consisting of plagioclase microlites in a cryptocrystalline matrix.

Qhp Dacite central plug (Pleistocene)--Light gray, slightly porphyritic shallow intrusion containing phenocrysts $(1-3 \mathrm{~mm})$ of wormy plagioclase (1-5 \%) in a fine-grained equigranular groundmass consisting of stubby plagioclase laths (90\%), othopyroxene (5-10\%), opaque minerals (1-2\%), and traces of biotite, clinopyroxene, and quartz. Clots of biotite and opaque minerals may be pseudomorphic after hornblende. An analyzed rock contains $66.3 \% \mathrm{SiO}_{2}$ (sample 91ARh-20, Table 2).

Qhdi Dacite shallow intrusion(?) (Pleistocene)--Light gray to light olive gray, poorly exposed, irregular dacite body. Rock contains phenocrysts of plagioclase (8-10\%) and orthopyroxene (trace) in an equigranular $(<1 \mathrm{~mm})$ groundmass of plagioclase, orthopyroxene, opaque minerals, quartz, and possibly potassium feldspar. Plagioclase is typically strongly oscillatory zoned and generally exhibits clear cores and wormy margins. Analyzed samples contain 66.8-67.1\% $\mathrm{SiO}_{2}$ (samples 91AMl-7B, 8B) Table 2). Exposed approximately $6.4 \mathrm{~km}$ east of the main eruptive center of the Ho-hum Creek complex where it intrudes(?) lavas of the Tumble Creek area. Considered part of the Ho-hum Creek complex because of its geochemical similarity to other rocks of the complex (figure 1). 
Dacite dome and flows (Pleistocene)--Undifferentiated dome rock and flows in central part of complex. Chiefly light gray to pale red porphyritic dacite containing phenocrysts $(2-5 \mathrm{~mm})$ of oscillatoryzoned plagioclase (3-15\%), hornblende rimmed with opaque minerals (trace-4\%), orthopyroxene (trace$3 \%)$, clinopyroxene $(0-2 \%)$, and an occasional trace of biotite and olivine in a cryptocrystalline to pilotaxitic groundmass of plagioclase needles and laths, sparse orthopyroxene, opaque minerals, and glass. Analyzed rocks contain 64.6-66.1 $\% \mathrm{SiO}_{2}$ (samples 91ARh-14, 91ARh-18, 91ASh-8, Table 2).

Qht Dacite tephra (Pleistocene)--Light gray to medium gray angular blocks of glassy dacite in an ash matrix. Dacite is sparsely porphyritic containing phenocrysts $(1-2 \mathrm{~mm})$ of plagioclase (1-2 \%), orthopyroxene (1-2 \%), and traces of hornblende, and opaque minerals in a brown glass groundmass containing as much as $40 \%$ microphenocrysts of plagioclase, orthopyroxene, and opaque minerals. An analyzed block contains $67.1 \% \mathrm{SiO}_{2}$ (sample 91AMI-20B, Table 2). Unit is poorly exposed in sec. 1, T.5 N., R.9 E. along north edge of quadrangle probably representing an early pyroclastic stage in the eruptive development of the Ho-Hum Creek dome complex.

Jarvis volcanic complex --Elongate series of eruptive centers that includes from south to

north: (1) main Jarvis, a large shield volcano possibly containing one or more nearly circular summit calderas, as much as $4 \mathrm{mi}(6.4 \mathrm{~km})$ in diameter, (2) middle Jarvis, a large cone or shield volcano, $7.5 \mathrm{mi}(12 \mathrm{~km})$ north of main Jarvis, and (3) north Jarvis, a large cone or shield volcano, similar to, and $4 \mathrm{mi}(6.4 \mathrm{~km})$ north of, middle Jarvis. Main Jarvis, which includes Mount Jarvis $(13,421$ ft $[4,091 \mathrm{~m}])$ and an unnamed 13,025 -ft-high $(3,970 \mathrm{~m})$ peak, $3 \mathrm{mi}(4.8$ $\mathrm{km})$ to the north is mostly ice-covered. A few windows through this ice cover at the heads of the Jacksina and Copper Glaciers, expose flat-lying lava flows that may be of intracaldera origin. Marked angular unconformities, that are interpreted as caldera margins were observed only in two restricted exposures on the west side of Mount Jarvis. The middle and north Jarvis centers, which are associated with unnamed peaks, $9,525-$ and $9,085-f t-h i g h$ respectively $(2,903$ and $2,769 \mathrm{~m})$, are mostly ice-free and both are composed of lava flows that dip gently away from each center. $\mathrm{K}$-Ar dates acquired during this 
study and earlier from the adjacent Nabesna A-5 quadrangle (Richter and Smith, 1976) indicate that the Jarvis eruptive centers were active chiefly between 0.7 and $1.7 \mathrm{Ma}$.

Qjdf Dacite flow(s) (Pleistocene)--Dark gray, strikingly porphyritic dacite or high-silica andesite containing phenocrysts (2-4 mm) of plagioclase (5$10 \%)$, clinopyroxene $(2-5 \%)$, orthopyroxene $\left(1-\frac{\%}{0}\right)$, and opaque minerals (trace) and clots of clinopyroxene \pm plagioclase \pm orthopyroxene in a hyalopilitic groundmass consisting of microphenocrysts of plagioclase and pyroxene in brown glass. An analyzed rock contains $62.9 \%$ $\mathrm{SiO}_{2}$ (sample 91-ARh-38, Table 2). Plagioclase has yielded a $\mathrm{K}-\mathrm{Ar}$ age of $0.79 \pm 0.04 \mathrm{Ma}$ (sample 91ASh-13, Table 1). Although source is probably local, dacite is considered a late product of the Jarvis magma chamber based on its chemical similarity to other Jarvis lavas (Fig. 1).

Qjd Dikes and plugs (Pleistocene)--Only a few of the dikes shown on the map were examined on the ground. Most were mapped from the air or from distant ridges. Dikes examined were dark gray, porphyritic, olivine-bearing two pyroxene andesites similar to many of the host Jarvis lavas. One of the olivine-bearing dikes contains $60.0 \% \mathrm{SiO}_{2}$ (sample 91ADf-19, Table 2). Most of the dikes observed occur around the north Jarvis eruptive center and appear to radiate from there. The one plug noted, shown on peak 9190' in sec. 18, T. 4 N., R.10 E., was not accessible. This plug and its enclosing lavas may be a remnant of a younger satellitic cone on the flank of the middle Jarvis eruptive center.

Qja Andesite flows (Pleistocene)--Undifferentiated lava flows and minor lahars and flow breccias from the Jarvis eruptive centers. Chiefly light medium gray to dark gray, moderately porphyritic, olivine-bearing two-pyroxene andesites containing phenocrysts $(1-3 \mathrm{~mm})$ of plagioclase (2-15 \%), clinopyroxene (0-4\%), orthopyroxene (trace-4\%), olivine (0-6\%), and opaque minerals $(0-1 \%)$ in intersertal, pilotaxitic, or hyalopilitic groundmasses consisting largely of plagioclase and pyroxene microlites in a cryptocrystalline or glass matrix. Glomerocrystic clots, of a variety of minerals, are present in most flows. Most common are clots of orthopyroxene + plagioclase + opaque minerals and plagioclase + orthopyroxene + clinopyroxene \pm olivine; many of the clots show evidence of melting. Unit includes a few 
aphanitic andesite flows and olivine-free twopyroxene andesite flows scattered through the exposed sections. Analyzed flows contain 55.2 to $60.0 \% \mathrm{SiO}_{2}$ (samples 91AMI-13, 17; 91ADf-17, 20; 91ASh-6, 14, Table 2). Plagioclase from flows from the middle Jarvis eruptive center yielded $\mathrm{K}$ Ar ages of $0.64 \pm 0.10 \mathrm{Ma}$ and $1.04 \pm 0.05 \mathrm{Ma}$ (samples 91ASh-14, 91ASh-5, Table 1). The $0.64 \mathrm{Ma}$ age suggests that the 9190-foot-peak in sec 18, T. 4 N., R.10 N. and its summit plug (unit Qji) are remnants of a younger eruptive center.

Qjb Basalt flows (Pleistocene)--Medium to dark gray porphyritic and fine-grained aphyric flows. Porphyritic flows contain phenocrysts $(1-3 \mathrm{~mm})$ of plagioclase (3-10 \%) that is oscillatory zoned and displays both clear and wormy cores and clear and wormy margins, olivine (1-4\%) that is both skeletal and euhedral, rounded orthopyroxene (trace-2 \%), and opaque minerals (trace) in a pilotaxitic to intersertal groundmass of olivine, orthopyroxene, and plagioclase microphenocrysts and dark glass. Clots of orthopyroxene, orthopyroxene + plagioclase, and plagioclase + olivine locally common. Aphyric flows consist of alined plagioclase laths (60-75 \%), clinopyroxene (10-20\%), granular olivine (10-15 \%) and opaque minerals; an analyzed sample contains 51.2 \% $\mathrm{SiO}_{2}$ (sample 91AMl-14B, Table 2). Flows represent some of the most primitive and least mixed rocks in the quadrangle. Observed only in two restricted localities along the east side of the Jarvis complex, where the flows underly andesitic Jarvis lavas ( $Q j a)$. On the REE distribution diagram in figure 1, this basalt plots off from all other Jarvis flows suggesting that these flows may not be related to Jarvis but may be related to the lavas of Tumble Creek and hence considerably older than indicated here.

Lavas of Tumble Creek--Older eruptive center (?) consisting chiefly of basaltic andesite, and andesite flows, lahars, and hyaloclastites and minor dacite flows and breccias.

QTtd Dacite flows? (Pleistocene or Pliocene)--Iight gray flows are sparsely porphyritic and contain phenocrysts (up to $4 \mathrm{~mm}$ ) of plagioclase (trace to $8 \%$ ), altered amphibole (trace to 4 \%), and traces of quartz and opaque minerals in a trachytic groundmass of plagioclase laths, anhedral quartz, opaque minerals, and cryptocrystalline material. Unit is poorly exposed but rocks appear to be interlayered with Tumble Creek lavas; 
alternatively rocks may be intrusive and related to younger Ho-hum complex.

QTta Andesite and basaltic andesite flows, lahars, and hyaloclastites (Pleistocene or Pliocene)--Chiefly medium-gray, olive gray, and dark greenish gray, locally amygdaloidal and moderately to sparsely porphyritic lavas containing phenocrysts (1-3 mm) of plagioclase (2-20\%), clinopyroxene (0-3\%), orthopyroxene $(0-4 \%)$, olivine $(0-5 \%)$, and opaque minerals in a pilotaxitic groundmass of plagioclase laths and needles, microcrystalline pyroxene and opaque minerals, and cryptocrystalline material. Plagioclase mostly oscillatory zoned with wormy margins; locally clean and unzoned. Olivine, where present, rimmed by orthopyroxene. Glomerocrystic clots of orthopyroxene + plagioclase \pm clinopyroxene \pm opaque minerals locally abundant. A sparsely porphyritic two-pyroxene andesite contains $57.5 \%$ $\mathrm{SiO}_{2}$ (sample 91ADf-23, Table 2).

Olivine basaltic andesite plugs, flows, cinder cones, and tuff.

Qbp Plug (Pleistocene)--Small plug of olivine-bearing, sparsely porphyritic basaltic andesite exposed in the extreme northwest corner of the quadrangle.

Qbf Flows (Pleistocene)--Rocks are chiefly medium dark gray to medium gray and sparsely

porphyritic containing phenocrysts (up to $4 \mathrm{~mm}$ ) of plagioclase (trace-5 \%), euhedral to skeletal fresh olivine (1-6\%), fresh clinopyroxene (0-3 $\%$ ), and opaque minerals (trace) in a pilotaxitic to trachytic groundmass of plagioclase, mafic mineral, and opaque mineral microphenocrysts and glass. Plagioclase phenocrysts are generally rounded and resorbed; some show resorbed cores and clear margins, others clear cores and resorbed margins. Glomerocrystic clots of olivine + plagioclase + orthopyroxene and of both orthopyroxene and clinopyroxene are locally abundant. Less common non-porphyritic rocks are pilotaxitic to intergranular and contain fresh euhedral olivine, plagioclase laths, granular pyroxene and opaque minerals, and minor glass or cryptocrystalline material. Flows contain $53.2-55.4 \% \mathrm{SiO}_{2}$ (samples 91ADf-13, 91AMl-9, 91ARh-45, 91ASh-10, Table 2). A flow in the extreme northeastern corner of the quadrangle yielded a whole rock $\mathrm{K}$-Ar age of $0.87 \pm 0.05 \mathrm{Ma}$ (sample 91ASh-10, Table 1) but unit may have relatively wide age range. Interlayered bed of 
lapilli tuff is denoted by dashed line labelled $t$. Flows are equivalent to the olivine andesite flows (unit Qf) mapped in the contiguous Nabesna B-6 quadrangle (Richter and others, 1993).

Qbc Cinder cones (Pleistocene)--Chiefly dark reddish-gray cones, severely modified by erosion, comprised of cinder, bombs, spatter, and finer-grained debris and occasional short, rootless flows. A sample from the cone contains $53.3 \% \mathrm{SiO}_{2}$ (sample 91ADf11, Table 2). This basalt and the basal Jarvis basalt (sample 91AMl-14B, unit Qjb) are the most primitive rocks identified in the quadrangle.

Qbt Tuff (Pleistocene)--Chiefly palagonitized air-fall lapilli tuff, accretionary lapilli, and ash in beds that range from $1 \mathrm{~cm}$ to more than $1 \mathrm{~m}$ thick. Lapilli and ash fragments consist mostly of glassy scoria containing olivine and plagioclase phenocrysts. Deposits probably in large part result from sub-glacial eruptive activity.

Qaa Andesite agglutinate (Pleistocene)-- Medium dark gray to dark gray high-silica andesite containing sparse, small phenocrysts $(1 \mathrm{~mm})$ of plagioclase $(1-4 \%)$, clinopyroxene (trace-2 \%), orthopyroxene (trace-1 \%), and opaque minerals (trace) and abundant clasts, as much as $1 \mathrm{~m}$ in diameter, of both vitric and lithic cogenetic (?) andesitic or dacitic debris in a cryptocrystalline to glass groundmass. Agglutinate is apparently a single flow as much as $60 \mathrm{~m}$ thick; it exhibits wellformed columnar joints above a vitrophyre base. An analyzed sample contains $59.8 \% \mathrm{SiO}_{2}$ (Richter and Smith, 1976). Source local; probably derived from the collapse of a large cinder/spatter cone in the area now covered by a younger dacitic center in the adjacent Nabesna A-5 quadrangle.

QTrd Rhyolite dome (Pleistocene or Pliocene)--Light olive gray to medium gray, sparsely to moderately microporphyritic containing microphenocrysts of normally zoned plagiclase (1-10\%) in a groundmass of plagioclase microlites, rusty patches, opaque minerals, and cryptocrystalline material. Dome is exposed chiefly in adjacent Nabesna A-5 quadrangle where rock contains altered hornblende and traces of both orthopyroxene and clinopyroxene and has a $\mathrm{SiO}_{2}$ content of $72.2 \%$ (Richter and Smith, 1976).

Andesite mudflows, hyaloclastites, tephra, dikes, and flows--Unit consists chiefly of volcanic fragmental rocks and minor intercalated flows intruded by a number of mostly northeast-trending 
dikes in the northwest part of quadrangle.

Younger than, or contemporaneous with, undivided older andesites (unit Tau).

QTai Andesite dikes (Pleistocene or Pliocene)--Medium gray to medium dark gray, aphanitic to porphyritic dikes as much as $3 \mathrm{~m}$ thick and as long as $1 \mathrm{~km}$. Porphyritic variants contain phenocrysts (up to 3 $\mathrm{mm})$ of plagioclase (1-10\%), olivine (1-2 \%), and orthopyroxene (trace-1 \%) in an intergranular to microcrystalline groundmass of plagioclase and pyroxene.

QTa Andesite mudflows, hyaloclastites, tephra, and flows (Pleistocene or Pliocene)--Chiefly crudely layered, brownish gray mudflows and hyaloclastites containing unsorted clasts of andesite, as much as $1 \mathrm{~m}$ in diameter, in a palagonitized ash (mud) matrix. Clasts are sparsely porphyritic andesite containing phenocrysts (up to $3 \mathrm{~mm}$ ) of plagioclase (trace-1 \%) and orthopyroxene (trace) in grayish black glass or cryptocrystalline material. Tephra consists of brown, tan, and gray, locally palagonitized, bedded andesitic debris ranging from lapilli to fine ash in size. Andesite flows, locally coarsely porphyritic, are scattered through the unit.

Tau older andesites and basaltic andesites, undivided (Pliocene)--Chiefly flat-lying to gently dipping flows, $3-8 \mathrm{~m}$ thick, exhibiting scoriaceous tops and bottoms, and lesser intercalated lahars and flow breccias. Flows range from medium gray to olive gray to dark gray, are locally amygdaloidal, and generally porphyritic. Most prevalent are porphyritic two-pyroxene andesites containing fine- to medium-grained phenocrysts (up to $4 \mathrm{~mm})$ of oscillatory-zoned plagioclase $(2-25$ $\%$ ), clinopyroxene (trace to $3 \%$ ), orthopyroxene (trace to $5 \%$ ), olivine $(0-1 \%)$, opaque minerals (trace to $1 \%$ ), and occasional traces of quartz and altered amphibole in a pilotaxitic groundmass of plagioclase laths, minute pyroxene grains, opaque minerals, and cryptocrystalline material. Glomerocrystic clots of plagioclase \pm opaque minerals \pm clinopyroxene \pm orthopyroxene are locally common. Olivine, where present, is generally rimmed by orthopyroxene. An olivinebearing flow contains $54.5 \% \mathrm{SiO}_{2}$ (sample 91ASh-7, Table 2) and an olivine-free flow contains $57.1 \% \mathrm{SiO}_{2}$ (sample 91AMl-11A, Table 2). Correlative flows in the adjacent Nabesna B-6 quadrangle give $\mathrm{K}$-Ar ages of 1.99 and $2.21 \mathrm{Ma}$ (Richter and others, 1993). A light-colored small 
intrusive body (labelled i) exposed on the steep valley wall above Copper Glacier was not examined on the ground.

\section{REFERENCES}

Hurst, J.I., 1968, The reconnaissance petrology of andesites from the Mt. Wrangell caldera, Alaska: Fairbanks, University of Alaska, M.S. thesis, 83 p.

Nye, C.J., 1983, Petrology and geochemistry of Okmok and Wrangell volcanoes, Alaska: Santa Cruz, University of California, Ph.D. dissertation, $208 \mathrm{p}$.

Richter, D.H., Duffield, W.A., Sawyer, D.A., Ratte', J.C. and Schmoll, H.R., 1994, Geologic map of the Gulkana A-1 quadrangle, south-central Alaska: U.S. Geological Survey Geologic Quadrangle Map GQ-1728, scale $1: 63,360$.

Richter, D.H., Ratte', J.C., Schmoll, H.R., Leeman, W.P., Smith, J.G., and Yehle, L.A., 1989, Geologic map of the Gulkana B-1 quadrangle, south-central Alaska: U.S Geological Survey Geologic Quadrangle Map GQ-1655, scale 1:63,360.

Richter, D.H., Smith, J.G., Lanphere, M.A., Dalrymple, G.B., Reed, B.L., and Shew, Nora, 1990, Age and progression of volcanism, Wrangell volcanic field, Alaska: Bulletin of Volcanology, V. 53, p.29-44.

Richter, D.H., Smith, J.G., Schmoll, H.R., and Smith, R.L., 1993, Geologic map of the Nabesna B-6 quadrangle, south-central Alaska: U.S. Geological Survey Geologic Quadrangle Map GQ-1688, scale 1:63,360.

Richter, D.H., and Smith, R.L., 1976, Geologic map of the Nabesna A-5 quadrangle, Alaska: U.S. Geological Survey Geologic Quadrangle Map GQ-1292, scale $1: 63,360$.

Wheately, M.R. and Rock, N.M.S., 1988, Spider: A Macintosh program to generate normalized multielement "spidergrams": American Mineralogist, v. 73, p. 919921. 
Table 1. K-Ar ages and analytical data on volcanic rocks from Nabesna A-6 quadrangle, Alaska

[Constants used were $40 \mathrm{~K} / \mathrm{K}=1.167 \times 10^{-4} \mathrm{~mol} / \mathrm{mol} ; \lambda_{\beta}=4.962 \times 10^{-10} /$ year; $\lambda_{\varepsilon}+\lambda_{\varepsilon}=0.581 \times 10^{-10} /$ year. Potassium analysts for the K-Ar dating were S.T. Pribble and T.L. Fries. Sample preparation, argon extraction, and data reduction by Nora Shew. Replicate $\mathrm{K}_{2} \mathrm{O}$ analyses shown in two rows. $\mathrm{HF}=$ treated with dilute hydrofluoric acid; $m W R=$ whole rock with mafic minerals removed; Plag = plagioclase; WR whole rock]

\begin{tabular}{|c|c|c|c|c|c|c|c|c|c|}
\hline $\begin{array}{l}\text { Locality } \\
\text { Number }\end{array}$ & $\begin{array}{l}\text { Map } \\
\text { Unit }\end{array}$ & $\begin{array}{l}\text { Sample } \\
\text { Number }\end{array}$ & $\begin{array}{c}\text { Location } \\
\text { Latitude }(\mathrm{N}) \\
\text { Longitude }(\mathrm{W})\end{array}$ & $\begin{array}{l}\text { Material } \\
\text { Dated }\end{array}$ & $\begin{array}{c}\mathrm{K}_{2} \mathrm{O} \\
\text { (weight \%) }\end{array}$ & $\begin{array}{l}{ }^{40} \mathrm{Ar}_{\text {rad }} \\
\mathrm{mols} / \mathrm{gm}\end{array}$ & $\% \mathrm{Ar}_{\text {rad }}$ & $\begin{array}{l}\text { Age } \\
(\mathrm{Ma})\end{array}$ & \\
\hline 8 & Qsp & $91 \mathrm{ASh}-1$ & $\begin{array}{r}62^{\circ} 9.2^{\prime} \\
143^{\circ} 54.6^{\prime}\end{array}$ & Plag-HF & $\begin{array}{l}0.706 \\
0.689\end{array}$ & $\begin{array}{l}6.0619 \times 10^{-13} \\
6.3931 \times 10^{-13}\end{array}$ & $\begin{array}{l}11.8 \\
15.5\end{array}$ & 0.621 & \pm 0.028 \\
\hline 38 & Qsd & $91 \mathrm{ASh}-3$ & $\begin{array}{r}62^{\circ} 12.8^{\prime} \\
143^{\circ} 52.5^{\prime}\end{array}$ & Plag-HF & $\begin{array}{l}0.484 \\
0.478\end{array}$ & $\begin{array}{l}7.5840 \times 10^{-13} \\
7.7829 \times 10^{-13}\end{array}$ & $\begin{array}{l}3.3 \\
3.2\end{array}$ & 1.11 & \pm 0.03 \\
\hline 23 & Qja & $91 \mathrm{ASh}-5$ & $\begin{array}{r}62^{\circ} 7.7^{\prime} \\
143^{\circ} 33.2^{\prime}\end{array}$ & Plag-HF & $\begin{array}{l}0.359 \\
0.354\end{array}$ & $\begin{array}{l}5.1645 \times 10^{-13} \\
5.4553 \times 10^{-13}\end{array}$ & $\begin{array}{r}7.9 \\
11.3\end{array}$ & 1.04 & \pm 0.05 \\
\hline 11 & Qha & 91 ASh-9 & $\begin{array}{r}62^{\circ} 14.9^{\prime} \\
143^{\circ} 37.6^{\prime}\end{array}$ & Plag-HF & $\begin{array}{l}0.406 \\
0.405\end{array}$ & $\begin{array}{l}6.6647 \times 10^{-13} \\
5.6835 \times 10^{-13}\end{array}$ & $\begin{array}{l}11.6 \\
15.9\end{array}$ & 1.06 & \pm 0.12 \\
\hline 33 & Qbf & $91 \mathrm{ASh}-10$ & $\begin{array}{r}62^{\circ} 14.2^{\prime} \\
143^{\circ} 34.2^{\prime}\end{array}$ & WR-HF & $\begin{array}{l}0.579 \\
0.572\end{array}$ & $\begin{array}{l}6.9579 \times 10^{-13} \\
7.4779 \times 10^{-13}\end{array}$ & $\begin{array}{l}4.9 \\
7.1\end{array}$ & 0.872 & \pm 0.046 \\
\hline 21 & Qjdf & $91 \mathrm{ASh}-13$ & $\begin{array}{r}62^{\circ} 2.2^{\prime} \\
143^{\circ} 31.0^{\prime}\end{array}$ & Plag-HF & $\begin{array}{l}0.458 \\
0.457\end{array}$ & $\begin{array}{l}5.1034 \times 10^{-13} \\
5.3875 \times 10^{-13}\end{array}$ & $\begin{array}{l}11.5 \\
12.4\end{array}$ & 0.789 & \pm 0.039 \\
\hline 28 & Qja & 91ASh-14 & $\begin{array}{r}62^{\circ} 7.8^{\prime} \\
143^{\circ} 38.4^{\prime}\end{array}$ & mWR-HF & $\begin{array}{l}1.037 \\
1.036\end{array}$ & $\begin{array}{l}1.0492 \times 10^{-12} \\
8.4589 \times 10^{-13}\end{array}$ & $\begin{array}{r}21.0 \\
7.0\end{array}$ & 0.635 & \pm 0.096 \\
\hline
\end{tabular}


Táble 2. Chemical analyses of volcanic rocks from the Nabesna A-6 qudrangle, Alaska.

\begin{tabular}{|c|c|c|c|c|c|c|c|c|c|}
\hline \multirow{4}{*}{$\begin{array}{l}\text { Map unit } \\
\text { Locality No. } \\
\text { Field No. }\end{array}$} & \multicolumn{4}{|c|}{ WRANGEU } & \multicolumn{5}{|c|}{ SANFORD } \\
\hline & Qwa & & Qwbf & Qsd & & Qsy & & Qsp & Qso \\
\hline & 1 & 2 & 3 & 4 & 5 & 6 & 7 & 8 & 9 \\
\hline & $91 \mathrm{ARh}-11$ & $91 \mathrm{AMI}-5$ & 91 ADf-8 & 91ARh-1 & 91ARh-8A & 91ARh-7 & $91 \mathrm{ARh}-10$ & 91AMI-3A & 91ADf-6 \\
\hline $\mathrm{SiO}_{2}$ & $\begin{array}{r}\text { weight } \% \\
61.30\end{array}$ & 62.60 & 51.20 & 64.00 & 62.00 & 55.80 & 54.40 & 66.70 & 62.40 \\
\hline $\mathrm{Al}_{2} \mathrm{O}_{3}$ & 16.60 & 16.50 & 17.80 & 15.50 & 15.80 & 15.70 & 15.50 & 14.70 & 15.90 \\
\hline $\mathrm{Fe}_{2} \mathrm{O}_{3}$ & 1.28 & 1.24 & 1.22 & 1.41 & 1.35 & 3.40 & 2.83 & 1.16 & 1.41 \\
\hline $\mathrm{FeO}$ & 3.84 & 3.39 & 6.91 & 3.97 & 5.33 & 5.56 & 7.36 & 2.20 & 4.44 \\
\hline $\mathrm{MgO}$ & 3.58 & 2.86 & 6.62 & 1.44 & 1.27 & 3.47 & 3.25 & 0.53 & 1.72 \\
\hline $\begin{array}{l}\mathrm{CaO} \\
\mathrm{Na}_{2} \mathrm{O}\end{array}$ & $\begin{array}{l}5.77 \\
3.80\end{array}$ & $\begin{array}{l}5.46 \\
3.78\end{array}$ & $\begin{array}{l}9.97 \\
3.18\end{array}$ & $\begin{array}{l}3.61 \\
4.41\end{array}$ & $\begin{array}{l}3.68 \\
4.77\end{array}$ & $\begin{array}{l}6.64 \\
3.54\end{array}$ & $\begin{array}{l}6.20 \\
4.30\end{array}$ & $\begin{array}{l}2.17 \\
4.50\end{array}$ & $\begin{array}{l}4.31 \\
4.50\end{array}$ \\
\hline $\mathrm{K}_{2} \mathrm{O}$ & 1.88 & 1.94 & 0.71 & 3.16 & 2.89 & 2.00 & 1.86 & 3.27 & 2.56 \\
\hline $\mathrm{TiO}_{2}$ & 0.82 & 0.69 & 1.27 & 1.05 & 1.00 & 1.92 & 2.09 & 0.51 & 1.15 \\
\hline $\mathrm{P}_{2} \mathrm{O}_{5}$ & 0.22 & 0.17 & 0.19 & 0.35 & 0.42 & 0.63 & 1.30 & 0.14 & 0.48 \\
\hline $\begin{array}{l}\mathrm{MnO} \\
\mathrm{H}_{2} \mathrm{O}+\end{array}$ & $\begin{array}{l}0.09 \\
0.08\end{array}$ & $\begin{array}{l}0.08 \\
0.25\end{array}$ & $\begin{array}{l}0.15 \\
0.34\end{array}$ & $\begin{array}{l}0.11 \\
0.13\end{array}$ & $\begin{array}{l}0.15 \\
0.14\end{array}$ & $\begin{array}{l}0.14 \\
0.52\end{array}$ & $\begin{array}{l}0.19 \\
0.04\end{array}$ & $\begin{array}{l}0.09 \\
2.56\end{array}$ & $\begin{array}{l}0.12 \\
0.15\end{array}$ \\
\hline $\mathrm{H}_{2} \mathrm{O}-$ & 0.01 & 0.04 & 0.04 & 0.02 & 0.01 & 0.15 & 0.07 & 0.38 & 0.05 \\
\hline $\mathrm{CO}_{2}$ & 0.01 & 0.02 & 0.01 & 0.02 & 0.02 & 0.01 & 0.02 & 0.02 & 0.01 \\
\hline total & 99.28 & 99.02 & 99.61 & 99.18 & 98.83 & 99.48 & 99.41 & 98.93 & 99.20 \\
\hline $\mathrm{SiO}_{2}$ anhydros & 61.81 & 63.42 & 51.60 & 64.64 & 62.84 & 56.48 & 54.79 & 69.50 & 63.04 \\
\hline & ppm & & & & & & & & \\
\hline $\mathrm{Nb} \quad \mathrm{XRF}$ & $<10$ & $<10$ & $<10$ & 18 & 19 & 13 & 13 & 13 & 19 \\
\hline $\mathrm{Rb} \quad \mathrm{XRF}$ & 44 & 56 & 13 & 71 & 68 & 51 & 40 & 84 & 64 \\
\hline $\mathrm{Rb}$ INAA & 45.6 & 51.1 & 12.5 & 77.3 & 69.5 & 48.7 & 44.2 & 86.8 & 69.0 \\
\hline $\mathrm{Sr} \quad \mathrm{XRF}$ & 570 & 495 & 480 & 355 & 345 & 485 & 440 & 265 & 420 \\
\hline Sr INAA & 633.00 & 549.00 & 570.00 & 434.00 & 401.00 & 558.00 & 499.00 & 271.00 & 450.00 \\
\hline $\mathrm{Zr} \quad \mathrm{XRF}$ & 184.00 & 182.00 & 122.00 & 475.00 & 510.00 & 355.00 & 395.00 & 495.00 & 425.00 \\
\hline$Y \quad X R F$ & 19.00 & 19.00 & 23.00 & 48.00 & 59.00 & 42.00 & 66.00 & 50.00 & 51.00 \\
\hline $\mathrm{Ba} \quad \mathrm{XRF}$ & 570.00 & 600.00 & 235.00 & 950.00 & 900.00 & 660.00 & 620.00 & 1100.00 & 900.00 \\
\hline $\mathrm{Ba}$ INAA & 558.00 & 605.00 & 244.00 & 942.00 & 845.00 & 642.00 & 605.00 & 1050.00 & 850.00 \\
\hline $\mathrm{Cu} \quad \mathrm{XRF}$ & 48.00 & 57.00 & 69.00 & 29.00 & 32.00 & 132.00 & 36.00 & 16.00 & 14.00 \\
\hline $\mathrm{Ni} \quad \mathrm{XRf}$ & 52.00 & 35.00 & 61.00 & $<10$ & $<10$ & 37.00 & $<10$ & $<10$ & $<10$ \\
\hline $\mathrm{Ni}$ INAA & 64.40 & 33.20 & 63.00 & nd & $n d$ & 50.00 & nd & nd & $<16$ \\
\hline $\mathrm{Zn} \quad \mathrm{XRF}$ & 56.00 & 47.00 & 64.00 & 72.00 & 99.00 & 71.00 & 102.00 & 66.00 & 87.00 \\
\hline $\mathrm{Zn}$ INAA & 52.80 & 57.40 & 81.60 & 75.50 & 98.00 & 84.10 & 110.00 & 63.30 & 81.20 \\
\hline $\mathrm{Cr} \quad \mathrm{XRF}$ & 62.00 & 23.00 & 136.00 & $<20$ & $<20$ & $<20$ & $<20$ & $<20$ & $<20$ \\
\hline $\mathrm{Cr}$ INAA & 86.70 & 46.20 & 156.00 & nd & nd & 24.50 & nd & nd & 2.00 \\
\hline Co INAA & 17.90 & 15.60 & 34.70 & 10.10 & 7.83 & 26.90 & 22.10 & 2.55 & 9.61 \\
\hline Cs INAA & 1.10 & 1.36 & $n d$ & 1.62 & 1.60 & 1.12 & 0.86 & 2.21 & 1.60 \\
\hline $\mathrm{Hf}$ INAA & 4.15 & 4.17 & 2.87 & 10.50 & 10.80 & 7.78 & 8.47 & 11.00 & 8.98 \\
\hline Ta INAA & 0.48 & 0.52 & 0.34 & 1.04 & 1.11 & 0.88 & 1.00 & 1.14 & 1.04 \\
\hline Th INAA & 5.33 & 5.72 & 1.27 & 7.89 & 6.84 & 5.42 & 4.55 & 9.31 & 7.43 \\
\hline U INAA & 2.00 & 2.24 & 0.36 & 2.86 & 2.71 & 2.08 & 1.78 & 3.63 & 2.40 \\
\hline Sc INAA & 13.70 & 13.50 & 30.40 & 13.50 & 15.40 & 22.70 & 22.80 & 8.38 & 14.50 \\
\hline La INAA & 17.70 & 16.60 & 9.35 & 36.30 & 37.30 & 31.20 & 36.10 & 39.60 & 36.70 \\
\hline $\mathrm{Ce}$ INAA & 38.00 & 35.60 & 22.60 & 82.80 & 88.30 & 71.80 & 90.80 & 88.10 & 75.00 \\
\hline Nd INAA & 17.80 & 16.80 & 14.90 & 42.20 & 47.00 & 37.60 & 55.60 & 41.40 & 37.00 \\
\hline Sm INAA & 3.83 & 3.60 & 3.85 & 8.93 & 10.60 & 8.77 & 13.30 & 8.73 & 8.92 \\
\hline Eu INAA & 0.99 & 0.85 & 1.30 & 1.93 & 2.49 & 2.02 & 3.31 & 1.70 & 2.00 \\
\hline Gd INAA & 3.50 & 3.45 & 4.28 & 8.57 & 10.00 & 8.19 & 12.50 & 8.04 & nd \\
\hline Tb INAA & 0.49 & 0.45 & 0.63 & 1.28 & 1.51 & 1.25 & 1.83 & 1.21 & 1.24 \\
\hline Tm INAA & 0.25 & 0.25 & 0.35 & 0.70 & 0.84 & 0.61 & 0.89 & 0.70 & \\
\hline $\mathrm{Yb}$ INAA & 1.63 & 1.60 & 2.24 & 4.37 & 5.27 & 3.78 & 5.43 & 4.49 & 4.19 \\
\hline LU INAA & 0.25 & 0.23 & 0.35 & 0.65 & 0.78 & 0.56 & 0.79 & 0.66 & 0.60 \\
\hline
\end{tabular}


Táble 2. Continued

\begin{tabular}{|c|c|c|c|c|c|c|c|c|c|}
\hline \multirow{2}{*}{$\begin{array}{l}\text { Map unit } \\
\text { Locality No. } \\
\text { Field No. }\end{array}$} & $\begin{array}{l}\text { Qha } \\
10\end{array}$ & 11 & $\begin{array}{l}\text { Qhad } \\
12\end{array}$ & 13 & $\begin{array}{c}\text { 10-HUM } \\
\text { Qhp } \\
14\end{array}$ & $\begin{array}{l}\text { Qhdi } \\
15\end{array}$ & 16 & 17 & $\begin{array}{c}\text { Qhd } \\
18\end{array}$ \\
\hline & 91 ADf-9 & 91ASh-9 & $91 \mathrm{AMI}-10 \mathrm{C}$ & 91ARh-21 & $91 \mathrm{ARh}-20$ & $91 \mathrm{AMI}-7 \mathrm{~B}$ & $91 \mathrm{AMI}-8 \mathrm{~B}$ & $91 \mathrm{ARh}-14$ & $91 \mathrm{ARh}-18$ \\
\hline $\mathrm{SiO}_{2}$ & 59.10 & 59.20 & 64.20 & 62.40 & 65.40 & 66.60 & 65.70 & 63.70 & 63.00 \\
\hline $\mathrm{Al}_{2} \mathrm{O}_{3}$ & 18.30 & 15.90 & 17.40 & 17.40 & 16.90 & 16.60 & 17.00 & 17.30 & 16.00 \\
\hline $\mathrm{Fe}_{2} \mathrm{O}_{3}$ & 2.61 & 1.73 & 1.58 & 1.81 & 1.92 & 2.02 & 1.33 & 1.79 & 2.76 \\
\hline $\mathrm{FeO}$ & 3.15 & 3.85 & 2.54 & 3.17 & 1.73 & 1.33 & 2.12 & 2.48 & 1.39 \\
\hline $\mathrm{MgO}$ & 3.57 & 4.67 & 2.07 & 2.71 & 1.70 & 1.26 & 1.42 & 1.91 & 2.09 \\
\hline $\mathrm{CaO}$ & 6.70 & 6.32 & 4.96 & 5.54 & 4.25 & 3.78 & 4.06 & 4.87 & 4.82 \\
\hline $\mathrm{Na}_{2} \mathrm{O}$ & 3.73 & 3.38 & 4.20 & 4.19 & 4.40 & 4.27 & 4.30 & 4.23 & 3.61 \\
\hline $\mathrm{K}_{2} \mathrm{O}$ & 1.12 & 1.96 & 1.52 & 1.35 & 1.60 & 1.75 & 1.69 & 1.51 & 2.83 \\
\hline $\mathrm{TiO}_{2}$ & 0.63 & 0.84 & 0.53 & 0.68 & 0.46 & 0.44 & 0.45 & 0.52 & 0.64 \\
\hline $\mathrm{P}_{2} \mathrm{O}_{5}$ & 0.18 & 0.23 & 0.19 & 0.20 & 0.19 & 0.19 & 0.18 & 0.23 & 0.22 \\
\hline MnO & 0.11 & 0.10 & 0.11 & 0.10 & 0.11 & 0.09 & 0.11 & 0.10 & 0.08 \\
\hline $\mathrm{H}_{2} \mathrm{O}+$ & 0.42 & 0.92 & 0.04 & 0.06 & 0.25 & 0.42 & 0.66 & 0.31 & 1.09 \\
\hline $\mathrm{H}_{2} \mathrm{O}-$ & 0.07 & 0.25 & 0.01 & 0.10 & 0.66 & 0.44 & 0.24 & 0.26 & 0.29 \\
\hline $\mathrm{CO}_{2}$ & 0.02 & 0.03 & 0.02 & 0.05 & 0.02 & 0.04 & 0.11 & 0.02 & 0.02 \\
\hline total & 99.71 & 99.38 & 99.37 & 99.76 & 99.59 & 99.23 & 99.37 & 99.23 & 98.84 \\
\hline $\mathrm{SiO}_{2}$ anhydros & 59.57 & 60.30 & 64.65 & 62.68 & 66.29 & 67.73 & 66.80 & 64.58 & 64.66 \\
\hline $\mathrm{Nb}$ XRF & $<10$ & $<10$ & 10.00 & $<10$ & $<10$ & $<10$ & $<10$ & $<10$ & $<10$ \\
\hline $\mathrm{Rb} \quad \mathrm{XRF}$ & 27.00 & 47.00 & 30.00 & 30.00 & 34.00 & 35.00 & 37.00 & 32.00 & 62.00 \\
\hline $\mathrm{Rb}$ INAA & 21.30 & 45.00 & 29.20 & 28.00 & 31.00 & 33.10 & 30.90 & 27.80 & 60.40 \\
\hline Sr $\quad X R F$ & 600.00 & 720.00 & 530.00 & 590.00 & 510.00 & 475.00 & 510.00 & 580.00 & 1000.00 \\
\hline Sr INAA & 667.00 & 790.00 & 583.00 & 610.00 & 550.00 & 531.00 & 571.00 & 649.00 & 1120.00 \\
\hline $\mathrm{Zr} \quad \mathrm{XRF}$ & 91.00 & 196.00 & 112.00 & 126.00 & 106.00 & 112.00 & 116.00 & 134.00 & 260.00 \\
\hline$Y \quad X R F$ & $<10$ & 12.00 & 18.00 & 18.00 & 13.00 & 11.00 & 15.00 & 13.00 & $<10$ \\
\hline $\mathrm{Ba} \quad \mathrm{XRF}$ & 435.00 & 750.00 & 590.00 & 510.00 & 630.00 & 660.00 & 650.00 & 570.00 & 1300.00 \\
\hline $\mathrm{Ba}$ INAA & 411.00 & 724.00 & 561.00 & 490.00 & 592.00 & 631.00 & 625.00 & 529.00 & 1210.00 \\
\hline $\mathrm{Cu} \quad \mathrm{XRF}$ & 53.00 & 56.00 & 27.00 & 31.00 & 16.00 & 13.00 & 16.00 & 21.00 & 72.00 \\
\hline $\mathrm{Ni} \quad \mathrm{XRf}$ & 36.00 & 49.00 & $<10$ & 16.00 & $<10$ & $<10$ & $<10$ & $<10$ & 15.00 \\
\hline $\mathrm{Ni}$ INAA & 37.90 & 56.00 & 11.80 & 25.00 & $<13.0$ & nd & nd & nd & nd \\
\hline $\mathrm{Zn} \quad \mathrm{XRF}$ & 61.00 & 61.00 & 50.00 & 51.00 & 52.00 & 47.00 & 52.00 & 50.00 & 45.00 \\
\hline $\mathrm{Zn} \quad$ INAA & 58.80 & 54.00 & 57.10 & 50.00 & 57.20 & 55.90 & 56.50 & 53.10 & 52.40 \\
\hline $\mathrm{Cr} \quad \mathrm{XRF}$ & 27.00 & 114.00 & $<20$ & $<20$ & $<20$ & $<20$ & $<20$ & $<20$ & $<20$ \\
\hline $\mathrm{Cr}$ INAA & 46.00 & 143.00 & 6.99 & 24.00 & 8.00 & 6.55 & 2.95 & 13.00 & 18.50 \\
\hline Co INAA & 19.00 & 21.20 & 11.70 & 14.60 & 8.82 & 7.25 & 8.09 & 10.10 & 12.10 \\
\hline Cs INAA & 0.45 & 0.60 & 0.54 & 0.40 & 0.60 & 0.59 & 0.78 & 0.60 & 0.75 \\
\hline $\mathrm{Hf}$ INAA & 2.26 & 4.63 & 2.55 & 2.82 & 2.34 & 2.75 & 2.64 & 2.98 & 6.10 \\
\hline Ta INAA & 0.22 & 0.34 & 0.45 & 0.33 & 0.47 & 0.52 & 0.53 & 0.39 & 0.35 \\
\hline Th INAA & 1.68 & 5.89 & 2.64 & 2.56 & 2.70 & 3.04 & 2.87 & 2.89 & 11.60 \\
\hline$U \quad$ INAA & 0.73 & 1.40 & 1.06 & 0.80 & 0.90 & 1.21 & 1.13 & 1.00 & 2.44 \\
\hline Sc INAA & 14.80 & 17.40 & 9.58 & 11.80 & 7.19 & 6.57 & 6.48 & 8.24 & 9.86 \\
\hline La INAA & 9.42 & 20.60 & 15.00 & 13.30 & 15.30 & 16.30 & 16.10 & 15.60 & 39.10 \\
\hline $\mathrm{Ce}$ INAA & 20.00 & 38.90 & 31.20 & 25.50 & 28.50 & 33.00 & 32.80 & 32.90 & 81.70 \\
\hline Nd INAA & 10.40 & 16.00 & 14.00 & 11.00 & 11.00 & 14.20 & 14.20 & 14.30 & 34.10 \\
\hline Sm INAA & 2.41 & 3.34 & 2.82 & 2.75 & 2.43 & 2.79 & 2.77 & 2.76 & 5.48 \\
\hline Eu INAA & 0.80 & 0.98 & 0.83 & 0.90 & 0.75 & 0.80 & 0.82 & 0.85 & 1.34 \\
\hline Gd INAA & 2.36 & nd & 2.54 & nd & nd & 2.31 & 2.29 & 2.57 & 3.62 \\
\hline Tb INAA & 0.32 & 0.41 & 0.36 & 0.40 & 0.31 & 0.33 & 0.34 & 0.35 & 0.42 \\
\hline Tm INAA & nd & nd & nd & nd & nd & nd & 0.18 & nd & nd \\
\hline $\mathrm{Yb}$ INAA & 1.19 & 1.40 & 1.19 & 1.40 & 1.10 & 1.15 & 1.20 & 1.26 & 0.95 \\
\hline Lu INAA & 0.19 & 0.21 & 0.18 & 0.21 & 0.16 & 0.18 & 0.18 & 0.20 & 0.14 \\
\hline
\end{tabular}


Táble 2. Continued

\begin{tabular}{|c|c|c|c|c|c|c|c|c|c|}
\hline $\begin{array}{l}\text { Map unit } \\
\text { Locality No. } \\
\text { Field No. }\end{array}$ & $\begin{array}{c}19 \\
91 \mathrm{ASH}-8 \\
\end{array}$ & $\begin{array}{c}\text { HO-HUM } \\
\text { Qht } \\
20 \\
91 \mathrm{AMI}-20 \mathrm{~B} \\
\end{array}$ & $\begin{array}{c}\text { Qjdf } \\
21 \\
91 \mathrm{ARh}-38 \\
\end{array}$ & $\begin{array}{c}\text { Qjd } \\
22 \\
91 \text { ADf-19 } \\
\end{array}$ & $\begin{array}{c}23 \\
91 \mathrm{AMI}-13 \\
\end{array}$ & $\begin{array}{l}\text { RVIS } \\
\text { Qja } \\
24 \\
\text { 91AMI-17 } \\
\end{array}$ & $\begin{array}{c}25 \\
91 \mathrm{ADf}-17 \\
\end{array}$ & $\begin{array}{c}26 \\
91 \mathrm{ADf}-20 \\
\end{array}$ & $\begin{array}{c}27 \\
91 \mathrm{ASh}-6 \\
\end{array}$ \\
\hline $\mathrm{SiO}_{2}$ & 64.60 & 66.10 & 62.30 & 59.20 & 56.70 & 55.40 & 56.40 & 59.10 & 56.10 \\
\hline $\mathrm{Al}_{2} \mathrm{O}_{3}$ & 16.30 & 16.90 & 16.30 & 16.00 & 16.60 & 18.90 & 18.40 & 16.80 & 18.20 \\
\hline $\mathrm{Fe} 2 \mathrm{O}_{3}$ & 1.72 & 1.65 & 1.11 & 1.59 & 1.43 & 1.90 & 2.57 & 1.84 & 3.55 \\
\hline $\mathrm{FeO}$ & 1.84 & 1.67 & 3.79 & 4.36 & 5.21 & 5.48 & 4.26 & 4.00 & 3.27 \\
\hline $\mathrm{MgO}$ & 2.12 & 1.50 & 3.03 & 4.14 & 5.10 & 4.22 & 3.79 & 4.22 & 3.70 \\
\hline $\mathrm{CaO}$ & 4.79 & 4.05 & 5.33 & 6.28 & 7.05 & 7.46 & 7.11 & 6.60 & 7.22 \\
\hline $\mathrm{Na}_{2} \mathrm{O}$ & 3.79 & 4.20 & 3.80 & 3.54 & 3.54 & 3.59 & 3.79 & 3.63 & 3.83 \\
\hline $\mathrm{K}_{2} \mathrm{O}$ & 2.07 & 1.73 & 2.21 & 2.12 & 1.54 & 1.24 & 1.37 & 1.80 & 1.39 \\
\hline $\mathrm{TiO}_{2}$ & 0.44 & 0.41 & 0.83 & 1.08 & 1.12 & 0.89 & 1.00 & 0.91 & 0.96 \\
\hline $\mathrm{P}_{2} \mathrm{O}_{5}$ & 0.16 & 0.18 & 0.20 & 0.31 & 0.31 & 0.22 & 0.26 & 0.22 & 0.27 \\
\hline $\mathrm{MnO}$ & 0.07 & 0.11 & 0.09 & 0.10 & 0.12 & 0.13 & 0.12 & 0.10 & 0.12 \\
\hline $\mathrm{H}_{2} \mathrm{O}+$ & 1.20 & 0.68 & 0.35 & 0.72 & 0.51 & 0.10 & 0.26 & 0.21 & 0.38 \\
\hline $\mathrm{H}_{2} \mathrm{O}-$ & 0.29 & 0.11 & 0.10 & 0.16 & 0.09 & 0.01 & 0.13 & 0.23 & 0.58 \\
\hline $\mathrm{CO}_{2}$ & 0.05 & 0.02 & 0.01 & 0.02 & 0.02 & 0.04 & 0.03 & 0.09 & 0.13 \\
\hline total & 99.44 & 99.31 & 99.45 & 99.62 & 99.34 & 99.58 & 99.49 & 99.75 & 99.70 \\
\hline $\mathrm{SiO}_{2}$ anhydros & 65.99 & 67.11 & 62.93 & 59.97 & 57.44 & 55.72 & 56.93 & 59.56 & 56.89 \\
\hline $\mathrm{Nb} \quad \mathrm{XRF}$ & $<10$ & $<10$ & $<10$ & 13.00 & $<10$ & $<10$ & $<10$ & $<10$ & $<10$ \\
\hline $\mathrm{Rb} \quad \mathrm{XRF}$ & 37.00 & 36.00 & 55.00 & 49.00 & 28.00 & 21.00 & 29.00 & 45.00 & 27.00 \\
\hline $\mathrm{Rb}$ INAA & 37.00 & 31.80 & 56.20 & 54.70 & 31.10 & 17.10 & 25.20 & 45.80 & 26.00 \\
\hline Sr $\quad X R F$ & 940.00 & 510.00 & 420.00 & 600.00 & 630.00 & 670.00 & 710.00 & 470.00 & 710.00 \\
\hline Sr INAA & 1010.00 & 564.00 & 514.00 & 672.00 & 702.00 & 753.00 & 788.00 & 566.00 & 780.00 \\
\hline $\mathrm{Zr} \quad \mathrm{XRF}$ & 130.00 & 106.00 & 235.00 & 265.00 & 194.00 & 126.00 & 158.00 & 196.00 & 160.00 \\
\hline$Y \quad X R F$ & $<10$ & 12.00 & 27.00 & 25.00 & 16.00 & 21.00 & 18.00 & 24.00 & 20.00 \\
\hline $\mathrm{Ba} \quad \mathrm{XRF}$ & 690.00 & 630.00 & 670.00 & 650.00 & 510.00 & 340.00 & 500.00 & 520.00 & 510.00 \\
\hline $\mathrm{Ba}$ INAA & 657.00 & 614.00 & 644.00 & 631.00 & 497.00 & 326.00 & 495.00 & 499.00 & 500.00 \\
\hline $\mathrm{Cu} \quad \mathrm{XRF}$ & 48.00 & 11.00 & 50.00 & 94.00 & 74.00 & 63.00 & 81.00 & 51.00 & 49.00 \\
\hline $\mathrm{Ni} \quad \mathrm{XRf}$ & 19.00 & $<10$ & 34.00 & 58.00 & 77.00 & 17.00 & 23.00 & 40.00 & 32.00 \\
\hline $\mathrm{Ni}$ INAA & 21.00 & na & 42.50 & 62.00 & 90.70 & nd & 37.50 & 52.70 & 39.00 \\
\hline $\mathrm{Zn} \quad \mathrm{XRF}$ & 50.00 & 47.00 & 55.00 & 61.00 & 65.00 & 60.00 & 54.00 & 48.00 & 59.00 \\
\hline $\mathrm{Zn}$ INAA & 45.00 & 55.40 & 50.90 & 58.50 & 63.90 & 64.90 & 64.80 & 53.30 & 62.00 \\
\hline $\mathrm{Cr} \quad \mathrm{XRF}$ & $<20$ & $<20$ & 36.00 & 79.00 & 118.00 & $<20$ & $<20$ & 78.00 & $<20$ \\
\hline $\mathrm{Cr}$ INAA & 26.50 & 8.44 & 68.10 & 89.40 & 138.00 & 26.90 & 29.30 & 96.50 & 28.70 \\
\hline Co INAA & 10.60 & 7.90 & 16.40 & 20.80 & 25.80 & 25.00 & 22.60 & 21.40 & 21.60 \\
\hline Cs INAA & 0.68 & 0.75 & 1.31 & 1.14 & 0.57 & 0.31 & 0.26 & 1.00 & 0.42 \\
\hline Hf INAA & 3.07 & 2.37 & 5.46 & 5.74 & 4.39 & 2.67 & 3.69 & 4.60 & 3.51 \\
\hline Ta INAA & 0.33 & 0.50 & 0.60 & 0.67 & 0.54 & 0.26 & 0.35 & 0.51 & 0.39 \\
\hline Th INAA & 3.49 & 2.75 & 6.61 & 7.00 & 4.87 & 1.33 & 3.50 & 5.49 & 3.59 \\
\hline U INAA & 0.98 & 1.06 & 2.51 & 2.59 & 1.49 & 0.60 & 1.02 & 2.10 & 0.88 \\
\hline Sc INAA & 8.72 & 6.53 & 13.90 & 16.70 & 19.00 & 17.60 & 17.90 & 18.20 & 17.00 \\
\hline La INAA & 14.60 & 15.50 & 21.20 & 26.20 & 24.90 & 9.31 & 18.30 & 18.90 & 17.40 \\
\hline $\mathrm{Ce}$ INAA & 26.60 & 31.50 & 47.20 & 56.70 & 53.20 & 21.30 & 38.50 & 41.80 & 33.90 \\
\hline $\mathrm{Nd}$ INAA & 12.00 & 14.50 & 21.40 & 27.70 & 25.40 & 11.60 & 18.80 & 19.70 & 15.00 \\
\hline Sm INAA & 2.16 & 2.54 & 4.54 & 5.59 & 4.90 & 2.89 & 3.96 & 4.21 & 3.50 \\
\hline Eu INAA & 0.66 & 0.76 & 1.10 & 1.31 & 1.33 & 0.99 & 1.18 & 1.09 & 1.07 \\
\hline Gd INAA & nd & 2.33 & 4.38 & 4.99 & 4.55 & 2.94 & 3.53 & 3.76 & nd \\
\hline Tb INAA & 0.25 & 0.31 & 0.65 & 0.75 & 0.63 & 0.45 & 0.54 & 0.60 & 0.47 \\
\hline Tm INAA & nd & 0.17 & 0.37 & na & nd & 0.24 & nd & 0.32 & nd \\
\hline Yb INAA & 0.73 & 1.01 & 2.28 & 2.28 & 1.80 & 1.51 & 1.72 & 1.99 & 1.60 \\
\hline Lu INAA & 0.12 & 0.16 & 0.34 & 0.34 & 0.28 & 0.23 & 0.26 & 0.29 & 0.24 \\
\hline
\end{tabular}


Table 2. Continued

\begin{tabular}{|c|c|c|c|c|c|c|c|c|c|}
\hline $\begin{array}{l}\text { Map unit } \\
\text { Locality No. } \\
\text { Field No. }\end{array}$ & $\begin{array}{c}28 \\
91 \mathrm{ASh}-14 \\
\end{array}$ & $\begin{array}{c}\text { Qjb } \\
29 \\
91 \mathrm{AMl}-14 \mathrm{~B} \\
\end{array}$ & $\begin{array}{l}\text { QTta } \\
30 \\
91 \mathrm{ADf}-23 \\
\end{array}$ & $\begin{array}{c}\text { Qbc } \\
31 \\
91 A D f-11 \\
\end{array}$ & $\begin{array}{c}32 \\
91 \mathrm{ADf}-13 \\
\end{array}$ & $\begin{array}{c}\text { Qbf } \\
33 \\
91 \mathrm{ASh}-10 \\
\end{array}$ & $\begin{array}{c}34 \\
91 \mathrm{ARh}-45 \\
\end{array}$ & $\begin{array}{c}\text { Taa } \\
35 \\
91 \text { ASh-7 } \\
\end{array}$ & $\begin{array}{c}36 \\
91 \mathrm{AMl}-11 \mathrm{a} \\
\end{array}$ \\
\hline $\mathrm{SiO}_{2}$ & 59.30 & 50.90 & 57.40 & 52.70 & 54.60 & 54.90 & 52.80 & 54.10 & 57.10 \\
\hline $\mathrm{Al}_{2} \mathrm{O}_{3}$ & 16.40 & 17.20 & 18.20 & 15.90 & 17.00 & 17.20 & 18.20 & 19.00 & 18.20 \\
\hline $\mathrm{Fe} 2 \mathrm{O}_{3}$ & 1.26 & 2.84 & 5.34 & 3.46 & 2.58 & 1.83 & 1.82 & 3.44 & 2.08 \\
\hline $\mathrm{FeO}$ & 4.27 & 7.08 & 1.73 & 4.24 & 5.00 & 5.50 & 4.91 & 3.96 & 4.58 \\
\hline $\mathrm{MgO}$ & 4.92 & 5.13 & 3.82 & 8.76 & 6.45 & 5.79 & 6.34 & 4.30 & 3.78 \\
\hline $\mathrm{CaO}$ & 6.39 & 8.06 & 6.90 & 7.64 & 7.59 & 7.67 & 9.75 & 8.36 & 6.91 \\
\hline $\mathrm{Na}_{2} \mathrm{O}$ & 3.53 & 3.77 & 4.00 & 3.00 & 3.58 & 3.69 & 3.08 & 3.78 & 3.98 \\
\hline $\mathrm{K}_{2} \mathrm{O}$ & 1.65 & 1.42 & 1.14 & 1.58 & 0.93 & 0.97 & 1.05 & 0.88 & 1.14 \\
\hline $\mathrm{TiO}_{2}$ & 0.76 & 2.02 & 0.86 & 1.18 & 1.10 & 1.13 & 0.93 & 1.11 & 0.87 \\
\hline $\mathrm{P}_{2} \mathrm{O}_{5}$ & 0.20 & 0.75 & 0.24 & 0.29 & 0.30 & 0.32 & 0.26 & 0.22 & 0.22 \\
\hline MnO & 0.10 & 0.18 & 0.13 & 0.13 & 0.13 & 0.13 & 0.12 & 0.12 & 0.12 \\
\hline $\mathrm{H}_{2} \mathrm{O}+$ & 0.53 & 0.09 & 0.34 & 0.36 & 0.41 & 0.37 & 0.32 & 0.35 & 0.57 \\
\hline $\mathrm{H}_{2} \mathrm{O}-$ & 0.16 & 0.04 & 0.49 & 0.42 & 0.08 & 0.15 & 0.14 & 0.43 & 0.20 \\
\hline $\mathrm{CO}_{2}$ & 0.02 & 0.01 & 0.03 & 0.02 & 0.01 & 0.02 & 0.02 & 0.01 & 0.01 \\
\hline total & 99.49 & 99.49 & 100.62 & 99.68 & 99.76 & 99.67 & 99.74 & 100.06 & 99.76 \\
\hline $\mathrm{SiO}_{2}$ anhydros & 60.03 & 51.23 & 57.54 & 53.29 & 55.01 & 55.38 & 53.19 & 54.50 & 57.69 \\
\hline $\mathrm{Nb}$ XRF & 10.00 & 18.00 & 16.00 & $<10$ & $<10$ & 10.00 & $<10$ & 13.00 & $<10$ \\
\hline $\mathrm{Rb} \quad \mathrm{XRF}$ & 36.00 & 25.00 & 50.00 & 32.00 & 14.00 & 15.00 & 19.00 & 17.00 & 26.00 \\
\hline Rb INAA & 36.00 & 24.20 & 53.20 & 30.30 & 12.90 & 19.00 & 20.00 & 15.00 & 24.00 \\
\hline Sr XRF & 520.00 & 700.00 & 220.00 & 740.00 & 580.00 & 580.00 & 830.00 & 550.00 & 560.00 \\
\hline Sr INAA & 560.00 & 802.00 & 240.00 & 817.00 & 627.00 & 630.00 & 890.00 & 610.00 & 590.00 \\
\hline $\mathrm{Zr} \quad \mathrm{XRF}$ & 180.00 & 265.00 & 500.00 & 198.00 & 134.00 & 140.00 & 114.00 & 120.00 & 140.00 \\
\hline$Y \quad X R F$ & 24.00 & 43.00 & 65.00 & 16.00 & 16.00 & 16.00 & 12.00 & 22.00 & 22.00 \\
\hline $\mathrm{Ba} \quad \mathrm{XRF}$ & 570.00 & 540.00 & 710.00 & 640.00 & 320.00 & 335.00 & 380.00 & 315.00 & 420.00 \\
\hline $\mathrm{Ba}$ INAA & 540.00 & 542.00 & 700.00 & 603.00 & 305.00 & 340.00 & 370.00 & 320.00 & 410.00 \\
\hline $\mathrm{Cu} \quad \mathrm{XRF}$ & 67.00 & 60.00 & $<10$ & 100.00 & 49.00 & 43.00 & 102.00 & 54.00 & 54.00 \\
\hline $\mathrm{Ni} \quad \mathrm{XRf}$ & 112.00 & 37.00 & $<10$ & 235.00 & 136.00 & 110.00 & 65.00 & 23.00 & 30.00 \\
\hline $\mathrm{Ni}$ INAA & 110.00 & 56.50 & $<14$ & 207.00 & 128.00 & 100.00 & 74.00 & 34.00 & 34.00 \\
\hline $\mathrm{Zn} \quad \mathrm{XRF}$ & 58.00 & 64.00 & 88.00 & 65.00 & 64.00 & 64.00 & 63.00 & 62.00 & 74.00 \\
\hline $\mathrm{Zn}$ INAA & 57.00 & 90.80 & 83.00 & 71.30 & 70.70 & 59.00 & 59.00 & 66.00 & 65.20 \\
\hline $\mathrm{Cr} \quad \mathrm{XRF}$ & 128.00 & 20.00 & $<20$ & 360.00 & 164.00 & 146.00 & 134.00 & $<20$ & $<20$ \\
\hline $\mathrm{Cr}$ INAA & 148.00 & 56.20 & $<2.0$ & 389.00 & 177.00 & 156.00 & 151.00 & 30.70 & 21.40 \\
\hline Co INAA & 22.40 & 30.40 & 1.35 & 36.40 & 30.70 & 27.60 & 29.80 & 26.10 & 21.10 \\
\hline Cs INAA & 0.74 & nd & 1.10 & 0.30 & 0.27 & 0.30 & 0.26 & 0.33 & 0.49 \\
\hline Hf INAA & 3.69 & 5.87 & 10.00 & 4.59 & 2.79 & 2.97 & 2.44 & 2.67 & 2.98 \\
\hline Ta INAA & 0.41 & 0.65 & 0.95 & 0.36 & 0.45 & 0.50 & 0.29 & 0.43 & 0.34 \\
\hline Th INAA & 3.96 & 4.14 & 5.29 & 4.22 & 1.32 & 1.50 & 2.11 & 1.52 & 2.05 \\
\hline U INAA & 1.40 & 1.06 & 2.00 & 1.04 & 0.51 & 0.52 & 0.63 & 0.51 & 0.59 \\
\hline Sc INAA & 16.80 & 24.70 & 11.80 & 20.70 & 19.60 & 19.60 & 24.20 & 21.90 & 16.20 \\
\hline La INAA & 16.20 & 27.60 & 29.50 & 19.70 & 12.80 & 13.50 & 15.70 & 11.30 & 12.60 \\
\hline $\mathrm{Ce}$ INAA & 31.70 & 66.10 & 63.80 & 42.50 & 27.90 & 27.70 & 32.10 & 23.10 & 24.90 \\
\hline Nd INAA & 14.00 & 35.50 & 35.00 & 19.80 & 15.70 & 15.00 & 16.00 & 12.00 & 12.00 \\
\hline Sm INAA & 3.39 & 7.99 & 8.87 & 4.21 & 3.85 & 3.74 & 3.51 & 3.30 & 3.16 \\
\hline Eu INAA & 0.94 & 2.45 & 2.16 & 1.24 & 1.18 & 1.19 & 1.10 & 1.06 & 1.00 \\
\hline Gd INAA & nd & 7.51 & nd & 3.84 & 3.60 & nd & nd & nd & nd \\
\hline Tb INAA & 0.49 & 1.07 & 1.39 & 0.53 & 0.52 & 0.55 & .44 & 0.52 & 0.48 \\
\hline Tm INAA & nd & 0.53 & nd & 0.28 & 0.28 & nd & nd & nd & nd \\
\hline Yb INAA & 1.60 & 3.15 & 5.75 & 1.70 & 1.69 & 1.78 & 1.30 & 1.80 & 1.70 \\
\hline LU INAA & 0.25 & 0.46 & 0.86 & 0.26 & 0.25 & 0.26 & 0.19 & 0.26 & 0.25 \\
\hline
\end{tabular}

All major oxides, except $\mathrm{FeO}, \mathrm{CO} 2, \mathrm{H} 2 \mathrm{O}+$, by X-ray fluorescence. Trace elements by XRF, energy-dispersive $\mathrm{X}$-ray fluorescence, and instrumental neutron activation analysis (INAA). All analyses performed in the laboratories of the U.S. Geological Survey; analysts: J.R. Budahn, R.J. Knight, J.S. Mee, and D.F. Siems, Denver, CO; J. Kent and M.G. Schutt, Menlo Park, CA; J.N. Grossman, Reston, VA. nd, not accurately determined. 


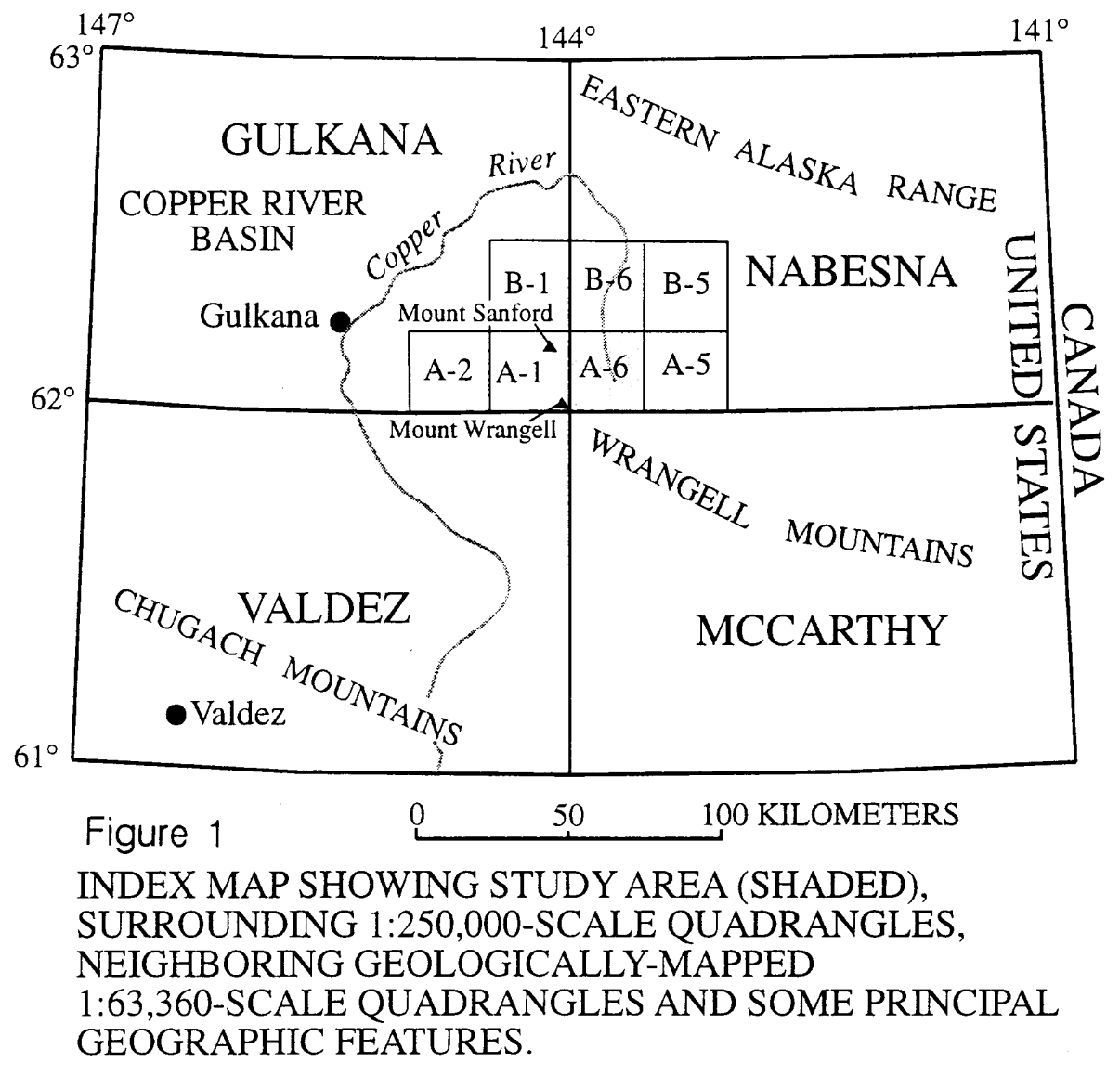




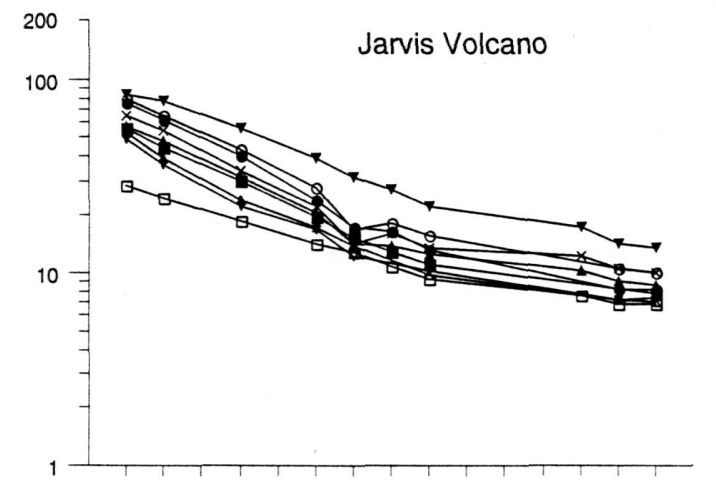

La Ce Pr Nd Sm Eu Gd Tb Dy Ho Er Tm Yb Lu

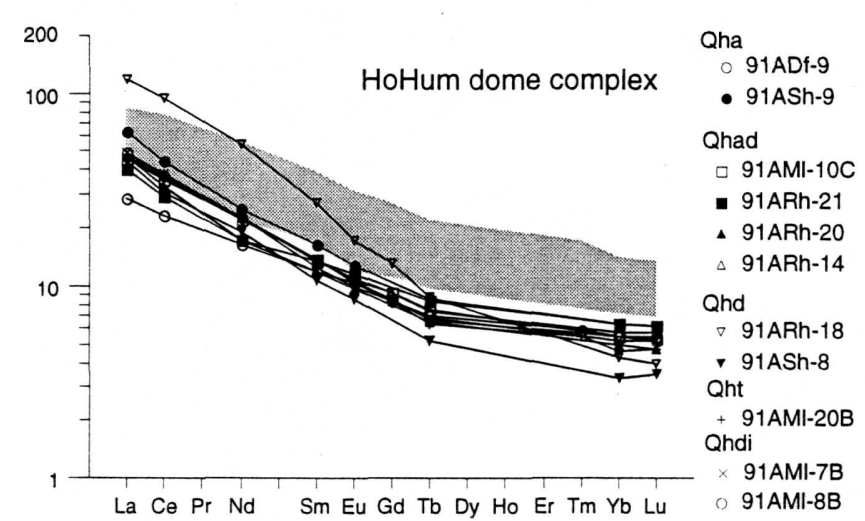

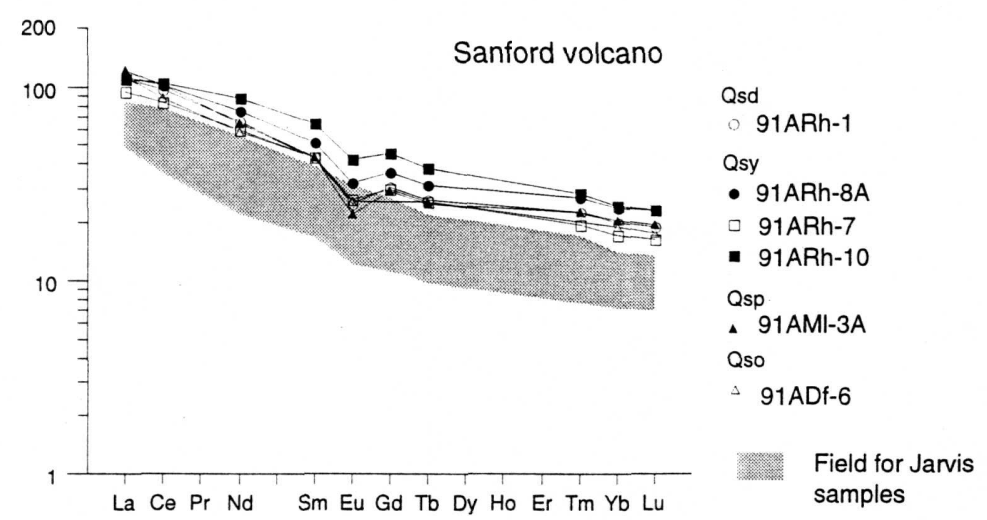

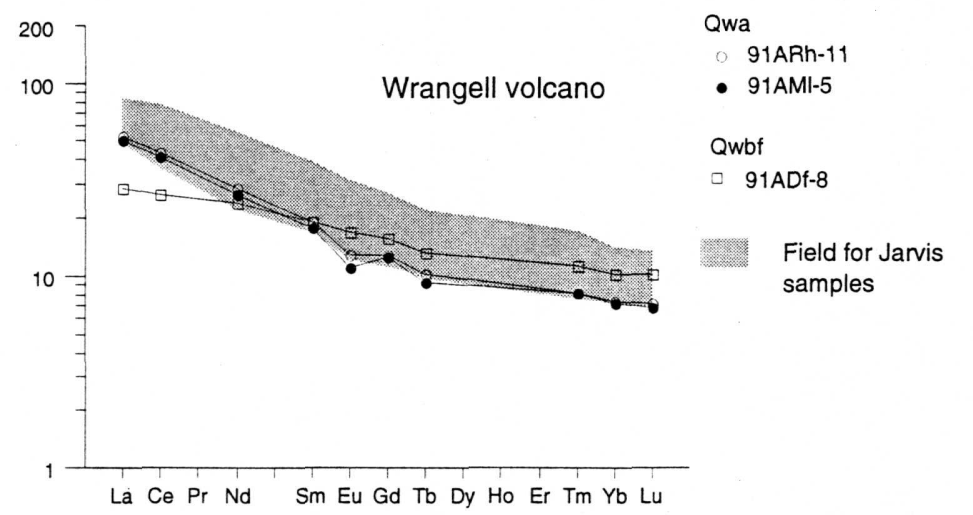

Figure 2. Rare earth element (REE) data, chondrite-normalized, for volcanic rocks from the Nabesna A-6 quadrangle. REE data for different volcanoes and eruptive centers have distinct REE patterns and were used to help determine the affinity of some samples. All of the sampled lavas from Sanford volcano have high total REE that plot above the field for Jarvis volcano, whereas the Wrangell volcano lavas have low REE contents that plot near the bottom of the Jarvis field. Sampled lavas from the HoHum dome complex have lower HREE contents than the Jarvis field. REE data were plotted using the program of Wheatley and Rock (1988). 


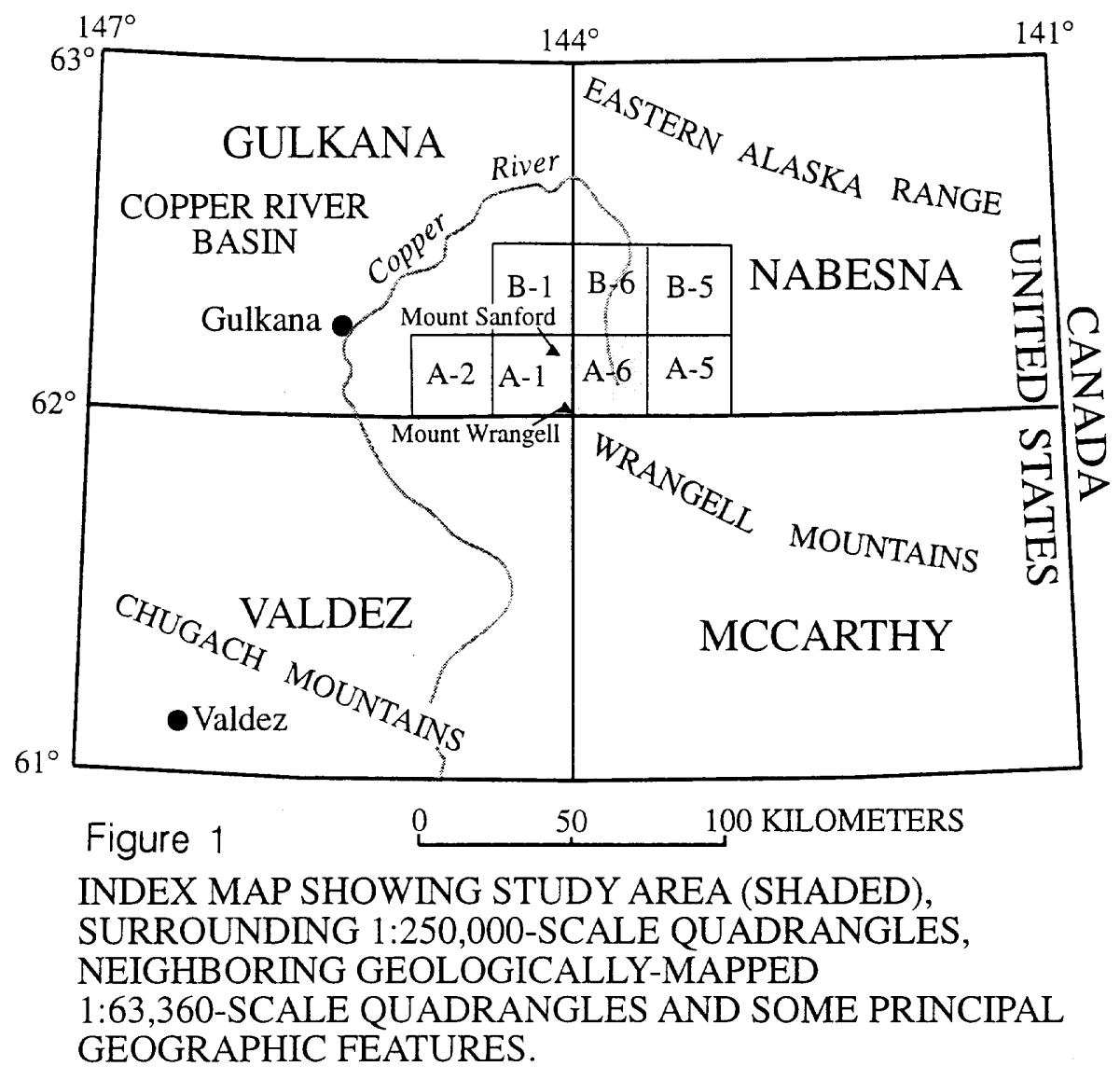

